New Manager For U OF T Forest

Mr. Norman L. Kissick, Northwestern Ontario Section, Canadian Institute of Forestry took over the position of Manager, University of Toronto Forest at Dorset, Ontario, on July 2, 1956. In addition to the management of the forest, Mr. Kissick will be an instructor in forestry at the Forest Ranger School at the same location. Students at the school are comprised of employees of the Department of Lands and Forests and also from the woods industry.

Mr. Kissick has been in the employ of Marathon Corporation of Canada Limited since 1948 and for the last several years as research forester. In his new capacity, he will be engaged in a research program on yellow birch and white pine in an endeavour to favor regeneration of these species after cutting.

\title{
Pilot Management Unit Established
}

The Alberta Forest Service has set aside an area of approximately 145 square miles of forest land in the Whitecourt area for a Pilot Management Unit which, in conjunction with Federal Government's Forestry Branch, will set up the basic patterns that may be applied to forest management practices in the Province.

Supervision and direction of the project will be carried under J. L. McLenahan, District Forest Officer of the Calgary Office of Federal Forestry Branch, with Earl Atkins acting as Forester for the project.

Provincial co-operation in the enterprise will be supervised by Director of Forestry, E. S. Huestis, with technical details between the two combining authorities under the care of Forest Management Assistant Superintendent, Charles Jackson, and R. D. Loomis, Sr. Superintendent, Forest Surveys, Alberta Forest Service.

It is expected that the field work will be completed this year for the preparation of a forest management plan, and experimental cutting under this plan should commence next year.

The area possesses a good variation of age classes up to and including mature timber, comprising mainly spruce and popular. However, there is actually a lack of overmature timber in this extensive zone, which obviously is in no way detrimental to this project.

By this means, it is anticipated that research and practical application will be much more closely organized and co-ordinated than heretofore, considering the broad regional scope of the enterprise.

\section{ERRATUM}

In the June 1956 Forestry Chronicle (Vol. 32(2) ) Page 169, Abstract 5 "The diffusion pressure deficit of water in roots" was prepared and presented by Dr. John L. Farrar and not Dr. Donald A. Fraser whose paper is reported in Abstract 7.

\section{DR. J. E. BIER JoIns U.B.C. STafF}

We have recently been advised that Dr. J. E. Bier has left the Forest Biology Division, Science Service, Department of Agriculture, Ottawa to accept a position in Forest Pathology at the University of British Columbia. 